\title{
AMPULLAE INFECTION OF THE MALPIGHIAN TUBULES OF Bombyx mori BY Alphabaculovirus
}

\author{
INFECÇÃO DE CÉLULAS DA AMPOLA DOS TÚBULOS DE MALPIGHI DE \\ Bombyx mori PELO Alphabaculovirus
}

\section{Marilucia SANTORUM ${ }^{1}$; Célia Cristina Leme BEU ${ }^{1}$; Lucinéia de Fátima Chasko RIBEIRO¹; Juliana Souza dos SANTOS ${ }^{2}$; Daniela Carvalho dos SANTOS ${ }^{3}$; Rose Meire Costa BRANCALHÃ ${ }^{1}$}

1. Programa de Pós-Graduação em Biociências e Saúde - PPGBS, Universidade Estadual do Oeste do Paraná, Cascavel, PR, Brasil. mari_santorum@hotmail.com; 2. Graduanda em Ciências Biológicas, Universidade Estadual do Oeste do Paraná, Cascavel, PR, Brasil; 3. Laboratório de Insetos, Departamento de Morfologia, Instituto de Biociências de Botucatu, UNESP, SP, Brasil.

\begin{abstract}
Alphabaculovirus is a genus of the entomopathogenic virus, whose species Bombyx mori nucleopolyhedrovirus (BmNPV) infects the silkworm, Bombyx mori, which is an important insect in the sericulture industry. A geographic isolate of BmNPV was identified in the state of Paraná, Brazil. It was infecting B. mori larvae and various organs and target tissues were identified, however, there was no information about the infection of Malpighian tubules (MT). The MT comprises the excretory system of B. mori and acts in the elimination of toxic substances and in hydroelectrolytic homeostasis. Thus, the present study examined the susceptibility and cytopathology of $B$. mori MT to BmNPV. To this end, hybrid fifth instar larvae were inoculated with a virus suspension at different days post-inoculation (dpi). MT segments were collected and divided into the ampullae, proximal, medial and distal regions. These were processed for light microscopy and transmission electron analysis. The MT regions revealed differences in susceptibility to BmNPV and the ampullae in its transition area was infected from the sixth dpi; the other regions did not reveal any evidence of infection. The transition area of the ampullae has not been previously described in Lepidoptera and its cytopathology revealed a hypertrophic nucleus with viroplasm, followed by the formation and development of viral polyhedra, which are common characteristics of infections by Alphabaculovirus. Thus, infection of the ampullae of the MT of B. mori by BmNPV, together with other known targets, compromises the metabolic balance of the insect, which results in consequences for silk production and damage to the sericulture sector.
\end{abstract}

KEYWORDS: Baculovirus. Bombyx mori. Silkworm. Cytopathology. Lepidoptera. Excretory system.

\section{INTRODUCTION}

Baculoviridae is a family of viruses that infect invertebrates, especially insects of the order Lepidoptera (BILIMORIA, 1991). It has been widely used as a bio-insecticide in the biological control of agricultural pests (DOURADO et al., 2011; MOSCARDI, 1999; RODRÍGUEZ et al., 2002). However, when it infects Bombyx mori (Lepidoptera Bombycidae) - an insect of economic importance - as in the case of Bombyx mori nucleopolyhedrovirus (BmNPV), genus Alphabaculovirus (AlphaBV), it triggers nuclear polyhedrosis disease, which results in damage to the sericulture industry (BRANCALHÃO, 2002; LIANG et al., 2013).

Nucleopolyhedroviruses (NPV) consist of circular double-stranded DNA, which is associated with capsid proteins that form the nucleocapsid. This is surrounded by a membranous envelope, forming the enveloped nucleocapsid, or virion, which may present one nucleocapsid per envelope, known as "single nucleopolyhedrovirus" (SNPV), or various "multiple nucleopolyhedrovirus" (MNPV) (ROHRMANN, 2013), which is considered to be more virulent. Furthermore, it appears that NPV of the same species may have genetic variability, depending on geographic location, which affects its virulence (ADAMS; McCLINTOCK, 1991; FAN et al., 2007; LIANG et al., 2013).

The cycle of infection of NPV presents two phenotypic forms: budded viruses (BV), which are not occluded, and which are responsible for systemic or secondary infection (cell-to-cell transmission); and occlusion derived bodies (ODB) that have one or more enveloped nucleocapsids, which are occluded in occlusion bodies (OB), and are responsible for the horizontal transmission of disease from one insect to another, acting in the primary infection of epithelial cells in the midgut (ROHRMANN, 2013).

A geographic isolate of BmNPV was identified in the state of Paraná, Brazil, which was infecting B. mori larvae. Various organs and target tissues have been previously identified in other studies, such as fat (BRANCALHÃO et al., 2002), 
integument (BRANCALHÃO; RIBEIRO, 2003) nerves (TORQUATO et al., 2006), testis (PEREIRA et al., 2008), cardia (RIBEIRO et al., 2009), the medial and posterior regions of the silk gland (BRANCALHÃO et al., 2009), the anterior region of the interstitial pyloric ring (BAGGIO et al., 2014) as well as the cells of the anal canal (VESSAROSILVA et al., 2014). However, there is no information in the literature of the action of this viral geographic isolate on the Malpighian tubules (MT) of B. mori.

The MT are the principal organ of the excretory system of insects; they are responsible for the elimination of toxic substances and assist in the hydroelectrolytic homeostasis of hemolymph (CHAPMAN, 1998). In B. mori, as in other Lepidoptera, the MT comprises six tubules, three on each side of the body of the insect, which unite to form a sac-like structure known as the ampullae in the region of the pyloric valve, the site of the junction of middle and posterior intestine (TEIGLER; ARNOTT, 1972; LEVY et al., 2004, 2008; MARANHÃO, 1978; RIGONI et al., 2004). The tubules can be further subdivided into three regions from the ampullae: the proximal, which extends to the middle portion of the midgut; the medial, with tubules that return to the pyloric valve; and the distal, with tubules that continue to the rectum, which makes up the cryptonephric system (FERMINO et al., 2010; RIGONI et al., 2004). Functionally, the proximal and medial sections act in the absorption of ions and the transport of fluids, forming urine (CHAPMAN, 1998; GULLAN; CRANSTON, 2010). The distal section reabsorbs water and recovers ions, an essential feature for insects, which cannot support large losses of ions from the hemolymph (CHAPMAN, 1998). In the case of the ampullae, Spring et al. (1988) consider that the function of the ampullae is to pump the urine into the intestine.

Morphologically, the MT consists of a simple epithelium tissue that is based on the basal lamina (MARTOJA; BALLAN-DUFRANÇAIS, 1984; SNODGRASS; EICKWORT, 1993; RAHMAN; GOPINATHAN, 2004), and an extensive network of tracheae, which perform aeration (CHAPMAN, 1998; SNODGRASS; EICKWORT, 1993).

Bearing in mind the role of the MT in the insect's metabolic balance, and the fact that osmoregulation influences the development of the silk gland (KATAOKA et al., 2009) and the functioning of other organs of the insect, this study evaluated the susceptibility of the MT of $B$. mori to BmNPV, geographic isolated in Paraná, Brazil, in order to contribute to the study of the establishment of its infectious cycle.

\section{MATERIAL AND METHODS}

\section{Insects and Inoculation}

Hybrid fourth instar B. mori larvae were obtained from a silk spinning company producing larvae for commercial purposes in the State of Paraná, Brazil. They were packed in polyethylene breeding boxes ( $28 \times 20.5 \times 10 \mathrm{~cm})$, kept in a breeding room and fed with fresh mulberry leaves (Morus sp.) three times daily.

The viral inoculum of BmNPV, geographically isolated in Paraná, Brazil, (GenBank accession number EU251694.1) was obtained from previously infected larvae and kept at a temperature of $-4^{\circ} \mathrm{C}$ (BRANCALHÃO et al., 2002). The viral suspension was quantified in a Neubauer chamber with a concentration of $2.8 \times 10^{7} \mathrm{POBs} / \mathrm{mL}(\mathrm{POBs}=$ polyhedral occlusion bodies).

Viral inoculation was performed on 50 larvae, which had fasted for 24 hours after ecdysis from the fourth to the fifth instar. The choice of this stage of development was due to the high metabolism of the insects, which is required for the energetic reserves necessary for metamorphosis and the construction of the cocoon. Furthermore, the size of the insects was appropriate for dissection. Mulberry leaf discs, $2 \mathrm{~cm}$ in diameter, were previously sprayed with $10 \mu \mathrm{L}$ of viral suspension ( $2.8 \times 10^{7}$ POBs). In the control, an equal number of larvae were fed leaf discs containing only water.

After ingesting the discs, the larvae (both inoculated and control) were placed in polyethylene boxes where they received routine feeding, free from the virus.

\section{Light Microscopy}

The larvae were randomly selected from the fourth to the ninth day post-inoculation (dpi); they were anesthetized in a freezer for about $5 \mathrm{~min}$, and then placed in a tube with cotton soaked in ethyl ether, and then dissected. The MT were removed and sectioned in the ampullae region, proximal, medial and distal. They were then packaged in individual vials containing Dubosq Brazil fixative (BEÇAK; PAULETE, 1976) for $24 \mathrm{~h}$ at $4^{\circ} \mathrm{C}$.

The MT samples were then submitted to the routine histological process for paraffin embedding (BRANCALHÃO et al., 2009). The slices were made using an Olympus CUT4055 microtome, 7 $\mu \mathrm{m}$ in thickness, and the slides that were obtained were subjected to hematoxylin-eosin (HE) staining (JUNQUEIRA; JUNQUEIRA, 1983) for 
morphological analysis, and modified Azan for viral occlusion bodies (HAMM, 1966). The control slides were subjected to the same preparations that were used for the inoculated material. After analysis, the images were obtained using an Olympus BX60 light microscope. The schematic representation of the transition area of the ampullae was performed using the Paint Tool SAI software program.

\section{Transmission Electron Microscopy}

For the transmission electron microscopy, the regions of the MT were sectioned and placed in previously identified individual vials containing modified Karnovsky fixative. They were fixed in $2.5 \%$ glutaraldehyde and $4 \%$ paraformaldehyde in $0.1 \mathrm{M}$ phosphate buffer at $\mathrm{pH} 7.3$ (KARNOVSKY, 1965). They were then washed three times in $0.1 \mathrm{M}$ phosphate buffer solution ( $\mathrm{pH} 7.3$ ) at intervals of 5 min each. Post-fixation was performed with $1 \%$ osmium tetroxide in the same buffer for $2 \mathrm{~h}$. The segments were washed three times in distilled water for $5 \mathrm{~min}$ each and then immersed in $0.5 \%$ uranyl acetate for $2 \mathrm{~h}$.

Dehydration was performed in solutions of $50 \%$ and $70 \%$ acetone, twice for $10 \mathrm{~min}$ each, and three times for $15 \mathrm{~min}$ in concentrations of $90 \%$ and $100 \%$. The regions were embedded in resin mixture (Araldite $($ ) ) and $100 \%$ acetone (1:1) at room temperature and in pure resin with polymerization in an oven at $60^{\circ} \mathrm{C}$ for $48 \mathrm{~h}$. Sections of $60-80 \mathrm{~nm}$ were made in ultramicrotome, and stained with alcoholic solution $(50 \%)$, saturated with uranyl acetate for 20 min, and lead citrate for $10 \mathrm{~min}$.
The examination and photographic documentation of the material was performed using a Philips CM100 transmission electron microscope at the Electron Microscopy Center of the Institute of Biosciences, Paulista State University, "Júlio de Mesquita Filho", Botucatu SP, and with a Zeiss EM900 equipment at the Central Complex for Research Support of the State University of Maringá, Paraná.

\section{RESULTS AND DISCUSSION}

The cytopathogical analyses of the regions of MT of $B$. mori revealed differences in susceptibility to BmNPV. In the proximal, medial and distal regions no evidence of viral infection was observed at any of the analyzed times, while in the ampullae, in the transition area to the proximal region, infected cells were found from the sixth dpi (Figure 1).

The transition area is a small region located at the end of the ampullae and the beginning of the proximal tubule region, whose cell morphology showed a continuous variation from squamous, which was characteristic of the ampullae, to cylindrical in the continuation with the proximal region. The distinction between the transition area and the proximal tubule region was easily identified due to the abrupt change in cell morphology, as indicated in Figure 1. The ampullae and its transition area were covered, on the apical surface, by the intima and supported by the basal lamina.

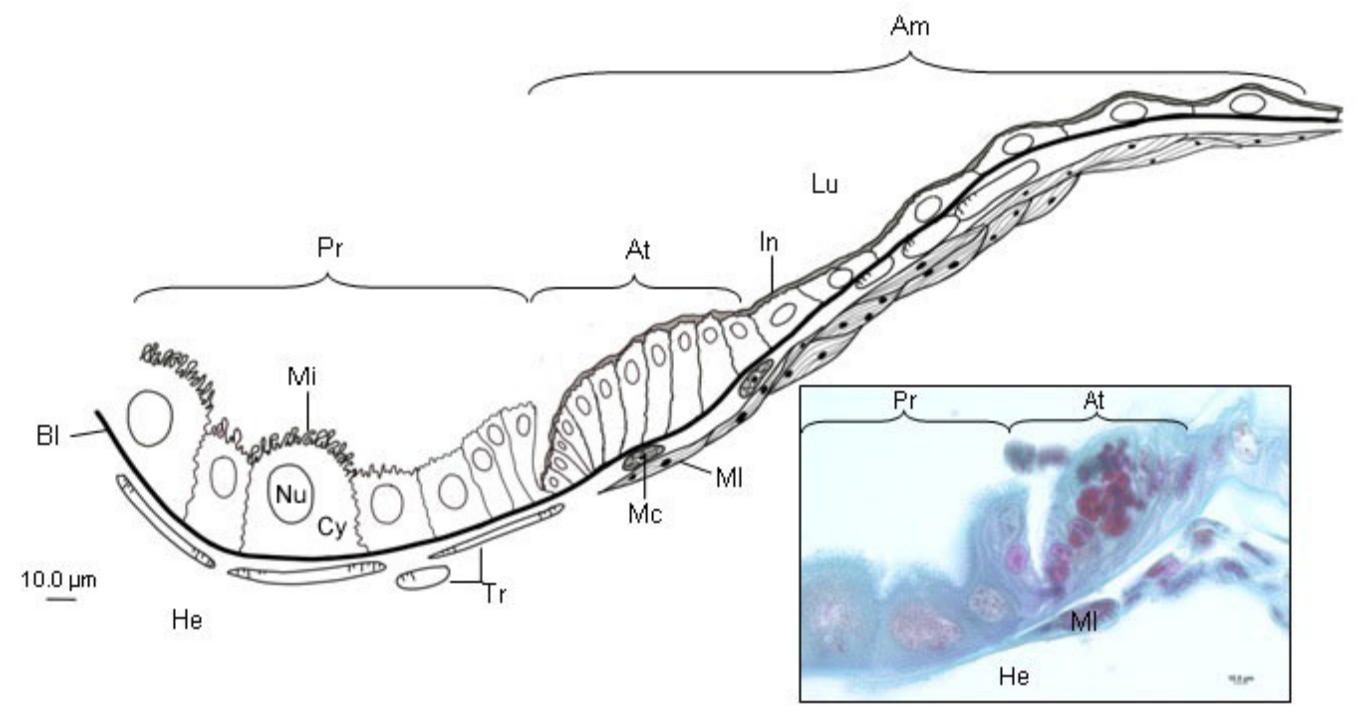

Figure 1. Schematic representation of the transition area (At) at the end of the ampulla (Am) and the start of the proximal region (Pr) of the Malpighian tubules of fifth instar B. mori larvae. Hemocoel (He), the tubule lumen ( $\mathrm{Lu})$ nucleus $(\mathrm{Nu})$, cytoplasm (Cy) microvilli (Mi), intima (In), basal lamina (Bl), trachea (Tr), circular muscle (Mc) and longitudinal muscle (Ml). In detail, electron micrograph of transition area of ampullae with viral polyhedra (in red) in the cell nucleus. Modified Azan staining. 
The presence of this transition area in the ampullae of MT has not been previously described in B. mori or other Lepidoptera. In the same way as other transition areas present in the insect's body, it is a target for BmNPV. Ribeiro et al. (2009) reported on the infection of the cardia, the transition area between the anterior and middle intestines of $B$. mori from the sixth dpi. Baggio et al. (2014) investigated the infection of the anterior area of the posterior interstitial ring of the pylorus, which marks the transition between the middle and posterior intestine, from the fifth dpi. The occurrence of infections by pathogenic microorganisms in transitional epithelia has also been reported in humans. Koss (1987) analyzed the papillomavirus infection of the transition zone in the squamocolumnar junction of the cervix, the epithelium of which varies from columnar to squamous, and justifies its propensity to infection due to rapid cell divisions that occur in the area.

The infection of the transition area of the ampullae of MT of B. mori is caused by BV that reach the organ via the tracheal system and hemolymph; $\mathrm{BV}$ are considered to be important dispersers of infection by AlphaBV in the bodies of insects (BRANCALHÃO et al., 2009; SOARES; RIBEIRO, 2005). The presence of a common lymphatic system in the tracheae permits a channel for the flow of BV to different tissues, which makes viral spread faster (ENGELHARD et al., 1994).

In the case of infection via hemolymph, the BV must cross the basal lamina, which is considered by many authors to be a semi-permeable barrier that acts as a selective filter to the passage of macromolecules (MEANS; PASSARELLI, 2010; RAHMAN; GOPINATHAN, 2004; SNODGRASS; EICKWORT, 1993) and pathogens such as virions (DOURADO et al, 2011; PASSARELI, 2011). Recent studies have shown that the basal lamina is a dynamic structure and that during the stages of its synthesis and degradation small pores occur, which allow the entry of virions (PASSARELLI, 2011).

Passarelli (2011) also discusses the fact that baculovirus encode a viral fibroblast growth factor (vFGF) that is contained in AlphaBV and which is involved in the passage of virions through the basal lamina. In the case of midgut cell infection the vFGF diffuses through the basal lamina, activating the receptor for FGF in the tracheal cells. These signaling events lead to the activation of caspases, which move through the extracellular medium and degrade the laminin of the basal lamina. This event allows the passage of $\mathrm{BV}$, which results in infection of the tracheal cells that aerate the organ. This same mechanism may allow the dispersion of BV to other tissues in the insect's body, as in the case of transition area of the ampullae of the MT.

The cytopathological examination of the transition area of the ampullae showed hypertrophic nuclei at different stages of the infectious cycle (Figure 2), which is a characteristic of the asynchronous replication of the virus (BRANCALHÃO, 2002; ROHRMANN， 2013). Initially it was possible to identify the formation of viroplasm or virogenic stroma (Figure 2B) a synthesis site of viral DNA and the assembly of the capsid, which gives rise to the nucleocapsids, followed by their enveloping, which results in enveloped nucleocapsids or virions (ADAMS; MACCLINTOCK, 1991). This process of viral enveloping occurs through microvesicles that are derived from the inner nuclear membrane and which are modified by the presence of viral proteins (ROHRMANN, 2013). Virions with one or more nucleocapsids per envelope were observed in the infected nucleus (Figure 2B), similar to what was reported by Brancalhão et al. (2009), who observed up to 11 nucleocapsids per envelope.

After the formation of the virions, the development of polyhedra occurred between the viroplasm and the nuclear envelope (Figure 2C) through the aggregation of the virions around the protein matrix of the polyhedra, which crystallized (ROHRMANN, 2013). Small-sized polyhedra, without defined geometric shape and which were non-enveloped were visible in the nuclei of infected cells, while others cells had larger polyhedra, with envelope and a defined geometric shape (Figure 2A, C and D). Brancalhão et al. (2009) classified these polyhedra as immature and mature, respectively; the geometric shape is provided by the envelope. The envelope or "calyx" acts to protect the virions, preventing their loss to the external environment (GROSS et al., 1994) and prevents the aggregation of the polyhedra (LIANG et al., 2013).

Variations in the size and quantity of the polyhedra were found in the infected nuclei. Torquato et al. (2006) measured the BmNPV of polyhedra, whose diameter varied from 2.5 to 4.5 $\mu \mathrm{m}$, and they described their characteristic geometric shape as being a truncated octahedron, however, they also discussed the presence of other shapes such as triangular, tetrahedral and hexahedral. Hong et al. (2000) found that the geometry of the BmNPV polyhedron was the result of genetic variation; according to Cheng et al. (2012) and Katsuma et al. (1999) this may be related to the occurrence of mutations in the polyhedrin. Torquato et al. (2006) noted that the positions of the 
polyhedron in microscopic preparations provide different angles, which increases this variation.
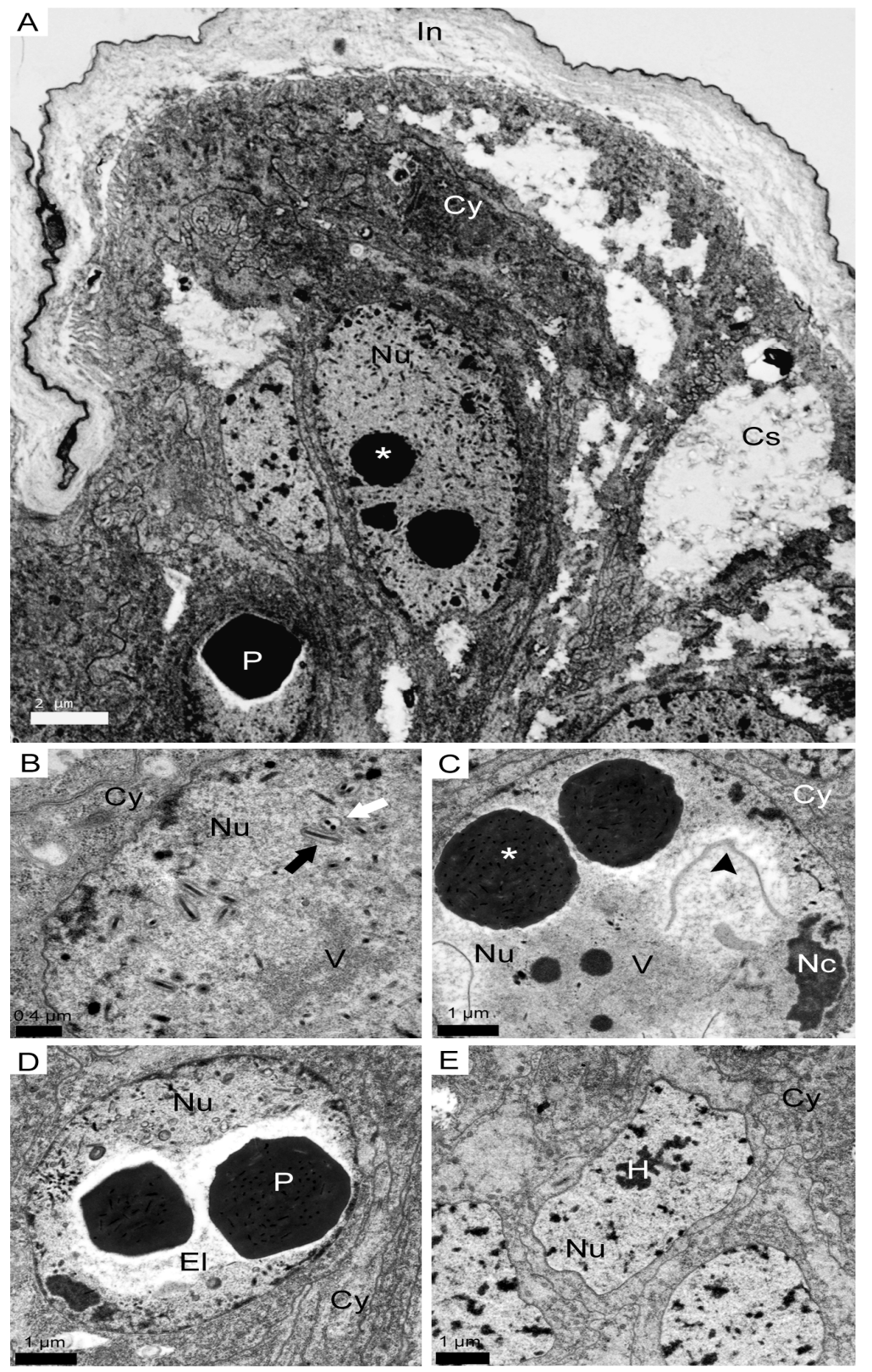

Figure 2. Electron micrographs of epithelial cells of the transition area of ampulla and the proximal region of the Malpighian tubules of fifth instar B. mori larvae inoculated with BmNPV, sixth dpi (A-E). In A: nuclei $(\mathrm{Nu})$ infected with polyhedra at different stages of development, immature $(*)$ and mature $(\mathrm{P})$, citoplama (Cy), cytoplasmic spaces (Cs) and intima (In), $2 \mu \mathrm{m}$. In B: nucleus with viroplasm (V), single enveloped nucleocapsid (black arrow) and multiple nucleocapsids (white arrow), $0.4 \mu \mathrm{m}$. In C: nucleus containing immature polyhedra $(*)$, the presence of membranous structures (arrowhead) and nucleolus $(\mathrm{Nc}), 1 \mu \mathrm{m}$. In D: mature polyhedra $(\mathrm{P})$ and electron-lucent regions $(\mathrm{El}), 1 \mu \mathrm{m}$. In E: control material for comparison, cytoplasm $(\mathrm{Cy})$, nucleus $(\mathrm{Nu})$ and heterochromatin $(\mathrm{H}), 1 \mu \mathrm{m}$.

Electron-dense membranous structures were identified in the infected nuclei, (Figure 2C), which seemed to be precursors of the polyhedron envelope (WILLIAMS et al., 1989) and the electron-lucent regions (Figure 2D) connected with the disintegration of the nucleoplasm (VAN OERS; VLAK, 1997). According to Carpentier et al. (2008) both these events are associated with the action of 
p10 multifunctional protein, which acts in the assembly of polyhedra, the disintegration of the nuclear envelope, and cell lysis.

At the end of the infection cycle the cytolysis of infected cells released mature polyhedra in the extracellular medium as well as hemocoel and lumen in the ampullae of the MT (not shown). Cell lysis is a characteristic of BmNPV infections (BAGGIO et al., 2014; RIBEIRO et al, 2009; VESSARO-SILVA et al., 2014) and due to luminal continuity the polyhedra can easily reach the intestine. According to Vessaro-Silva et al. (2014), one of the typical signs of infection by the BmNPV virus is the release of the virus into the environment through the anus, which enables the horizontal transmission of the disease. In this regard, Potrich et al. (2007) and Liang et al. (2013) call attention to the importance of disease control measures that when larvae are identified with signs of nuclear polyhedrosis sericulture producers should eliminate them, thereby limiting or preventing the spread of the pathogen, as well as disinfecting the environment.

As previously mentioned, in this study it was possible to verify the absence of infection in the proximal regions (Figure 1), as well as middle and distal regions of the MT by BmNPV, which may have been related to defense mechanisms whose genetic basis are still almost unknown (FAN et al., 2013; QIN et al., 2012). Adams and McClintock (1991) noted that the absence of infection in some cells is due to the differential expression of viral genes inserted into the genome of the host cells, given that the NPV present asynchronous replication. Rohrmann (2013) attributes the resistance of specific cell types to the expression of beta- $\mathrm{N}$-acetylglucosaminidase- 2 and aminoacylase proteins, which influence the activity of the fusion protein of the GP64 viral envelope, changing the infective capacity of the BV.

Cordeiro et al. (2008) also reported the absence of infection in the MT cells of Anticarsia gemmatalis (Lepidoptera: Noctuidae) larvae that were infected with recombinant AgMNPV baculovirus. However, they also described the premature degeneration of the MT with morphological changes in the epithelium, which was possibly due to apoptosis resulting from impaired oxygenation and nutrient transport to the MT. This impairment was due to the infection of the trachea and hemocytes, which especially affects tissues and organs with high metabolic activity. The early degeneration of the MT has also been observed by other authors (FLIPSEN et al, 1995; SOARES; RIBEIRO, 2005), which may have been related to the asynchronous replication of baculovírus (BRANCALHÃO et al., 2002).

However, Chakrabarty et al. (2012) demonstrated the infection of the MT of B. mori by BmNPV with changes in the epithelium tissue and the presence of the $\mathrm{OB}$ and $\mathrm{BV}$ virus in the apical surface of the cells. The different response to the infection of MT in the aforementioned study may have been related to the viral geographic isolate that was used because, according to Adams and McClintock (1991), Fan et al. (2007) and Liang et al. (2013), geographic isolates may present genetic variation that affects their virulence. In addition, the race and the lineage of $B$. mori that are used are factors to be considered because they contribute to differential response to infection (YAO et al., 2003).

Thus, the infection of transition areas, such as the ampullae of the MT of B. mori, to BmNPV, coupled with other known targets, negatively affects the hydroelectrolytic homeostasis of hemolymph and the elimination of toxic substances, which affects the insect's metabolic balance and which results in consequences for silk production and damage to the sericulture sector.

\section{ACKNOWLEGEMENTS}

The authors would like to thank the Coordination of Higher Education Personnel Training (CAPES) and Araucaria foundation for the research productivity scholarship opportunity, $\mathrm{CNPq}$ process number 443952/2014-0, Electron Microscopy Center of UNESP-Botucatu and UEM, and the Biosciences and Health Master's program at UNIOESTE for the use of their infrastructure.

RESUMO: Alphabaculovirus é um gênero de vírus entomopatogênico, cuja espécie Bombyx mori nucleopolyhedrovirus (BmNPV) infecta o bicho-da-seda, Bombyx mori, inseto importante na indústria sericícola. Um isolado geográfico do BmNPV foi identificado no estado do Paraná, Brasil, infectando lagartas de $B$. mori e vários órgãos e tecidos alvos foram identificados; entretanto, não há informações sobre a infecção do túbulo de Malpighi (TM). O TM compõe o sistema excretor de $B$. mori, atuando na eliminação de substâncias tóxicas e na homeostase hidroeletrolítica. Assim, o presente estudo, analisou a susceptibilidade e a citopatologia do TM de B. mori ao BmNPV. Para tanto, lagartas híbridas de $5^{\circ}$ instar foram inoculadas com uma suspensão viral e em diferentes dias pós-inoculação (dpi), segmentos do 
TM foram coletados e subdivididos nas regiões da ampola, proximal, média e distal; sendo processados para análises em microscopias de luz e eletrônica de transmissão. As regiões do TM revelaram diferenças na susceptibilidade ao BmNPV e a ampola, na sua área de transição, foi infectada a partir do $6^{\circ}$ dpi, já as demais regiões não revelaram quaisquer indícios de infecção. A área de transição da ampola, ainda não havia sido descrita em lepidópteros e sua citopatologia revelou núcleo hipertrófico com viroplasma, seguido da formação e desenvolvimento dos poliedros virais, características comuns das infecções pelo Alphabaculovirus. Assim, a infecção da ampola do TM de B. mori ao BmNPV, somada a de outros alvos conhecidos, compromete o equilíbrio metabólico do inseto, com consequências na produção de seda e prejuízos ao setor sericícola.

PALAVRAS-CHAVE: Baculovírus. Bombyx mori. Bicho-da-seda. Citopatologia. Lepidoptera. Sistema excretor.

\section{REFERENCES}

ADAMS, J. R.; MCCLINTOCK, J. T. Baculoviridae. Nuclear polyhedrosisviruses Part 1. Nuclear polyhedrosis viruses of insects. In: Atlas of Invertebrate Viruses. CRC Press, Florida, p. 89-180, 1991.

BAGGIO, M. P. D.; RIBEIRO, L. F. C.; VESSARO-SILVA, S. A.; BRANCALHÃO, R. M. C. Bombyx mori Pylorus Infection by Alphabaculovirus. Genetics and Molecular Research, v. 1, p. 1-8, 2014.

https://doi.org/10.4238/2014.april.3.3

BEÇAK, W.; PAULETE, J. (Eds.), 1976. Técnicas de citologia e histologia, vol. I. Técnicas de citologia e histologia, Rio de Janeiro.

BILIMORIA, S. L. The biology of nuclear polyhedrosis viruses. In: KURSTAK, E. Viruses of invertebrates. New York: Marcel Dekker, p. 1, 1991.

BRANCALHÃO, R. M. C. Vírus entomopatogênicos no bicho-da-seda. Biotecnologia Ciência \& Desenvolvimento, v. 24, p. 54-58, jan/fev, 2002.

BRANCALHÃO, R. M. C; SOUZA, V. B. B; SOARES, M. A. M. Infecção causada por Nucleopolyhedrovirus nas células gordurosas de Bombyx mori L.,1758 (Lepidoptera: Bombycidae). Arquivos do Instituto Biológico, São Paulo, v. 69, n. 2, p. 57-63, abrljun, 2002.

BRANCALHÃO, R. M. C.; RIBEIRO, L. F. C. Citopatologia da infecção causada pelo BmNPV no tegumento de Bombyx mori L.1758 (Lepidoptera: Bombycidae). Arquivos de Ciências Veterinárias e Zoologia da Unipar, Umuarama, v. 6, n. 1, p.15-20, 2003.

BRANCALHÃO, R. M. C.; TORQUATO, E. F. B.; FERNANDEZ, M. A. Cytopathology of Bombyx mori (Lepidoptera: Bombycidae) silk gland caused by multiple nucleopolyhedrovirus. Genetics and Molecular Research, Ribeirão Preto, v. 8, n. 1, p. 162-172, 2009. https://doi.org/10.4238/vol8-1gmr545

CARPENTIER, D. C. J.; GRIFFITHS, C. M.; KING, L. A.The baculovirus P10 protein of Autographa californica Nucleopolyhedrovirus forms two distinct cytoskeletal-like structures and associates with polyhedral occlusion bodies during infection. Virology, v. 371, p. $278-291,2008$.

https://doi.org/10.1016/j.virol.2007.09.043

CHAKRABARTY, S.; DEB, S.; SAHA, A. K.; MANNA, B.; BINDROO, B. B. Dimorphisim in nuclear polyhedrosis virus (BmNPV) (Family: Baculoviridae) causing 'grasserie' disease in silkworm (Bombyxmori L.): light and electron microscopy and protein profile. Applied Biological Research, v.14, n. 2, p. 176-186, 2012. 
CHAPMAN, R. F. The Insects: Structure and Function. $4^{\text {th }}$ Cambridge. Cambridge University Press, v. 3, p. 478-501, 1998. https://doi.org/10.1017/CBO9780511818202.019 https://doi.org/10.1017/CBO9780511818202

CHENG, R. L.; XU, Y. P.; ZHANG, C. X. Genome Sequence of a Bombyx mori nucleopolyhedrovirus Strain with Cubic Occlusion Bodies. Journal Virology, v. 86, p. 10245, 2012. https://doi.org/10.1128/JVI.01639-12

CORDEIRO, B. A.; TIBÚRCIO, V. H. S.; HALLWASS, M.; PAES, H. C.; RIBEIRO, B. M.; BÁO, S. N. Structural and ultrastructural alterations of Malpighian tubules Of Anticarsiagemmatalis (Hubner) (Lepidoptera: Noctuidae) larvae infected with different Anticarsia gemmatalis multiple nucleopolyhedrovirus (AgMNPV) recombinant viruses. Journal of Invertebrate Pathology, v. 98, p. 7-19, 2008. https://doi.org/10.1016/j.jip.2008.01.001

DOURADO, L. A.; RIBEIRO, L. F. C; BRANCALHÃO, R.M.C; TAVARES,J; BORGES, A. R; FERNANDEZ, M. A. Silkworm salivary glands are not susceptible to Bombyx mori nuclear polyhedrosis vírus. Genetics and Molecular Research, Ribeirão Preto, v. 10, n. 1, p. 335-339, 2011. https://doi.org/10.4238/vol10-1gmr996

ENGELHARD, E. K.; KAM MORGAN, L. N. W.; WASHBURN, J. O.; VOLKMAN, L. E. The insect tracheal system: A conduit for the systemic spread of Autographa californica M nuclear polyhedrosis virus.

Proceedings of the National Academy of Sciences of the United States of America, v. 9, p. 3224-3227, 1994. https://doi.org/10.1073/pnas.91.8.3224

FAN, Q.; LI, S.; WANG, L.; ZHANG, B.The genome sequence of the multicapsid nucleopolyhedrovirus of the Chinese oak silkworm Antheraea pernyi. Virology, v.366, p.304-315, 2007.

https://doi.org/10.1016/j.virol.2007.04.027

FERMINO, F.; CONTE, H.; FALCO, J. R. P. Analysis of Nucleus Activity in Malpighian Tubules of Diatraea saccharalis (Fabricius) (Lepidoptera: Crambidae) Larvae by Critical Electrolyte Concentration. Neotropical Entomology, v. 39, n. 4, p. 568-571, 2010. https://doi.org/10.1590/S1519-566X2010000400016

FLIPSEN, J.T.M.; MAN, R.M.W.; KLEEFSMAN, A.W.F.; KNEBEL-MORSDORF, K.; VLAK, J.M. Deletion of the baculovirus ecdysteroid UDPglucosyltransferase gene induces early degeneration of Malpighian tubules in infected insects. Journal of Virology, v. 69, n. 7, p. 4529-4532, 1995.

GROSS, C.H.; RUSSELL, R. L.; ROHRMANN, G. F. Orgyia pseudotsugata baculovirus p10 and polyhedron envelope protein genes: analysis of their relative expression levels and role in polyhedron structure. Journal of General Virology, v. 75, p. 1115-1123, 1994. https://doi.org/10.1099/0022-1317-75-5-1115

GULLAN, P.J.; CRANSTON, P.S. The insects an outline of entomology. $4^{\text {th }}$ edition. Wiley-Blackwell, Malaysia, 2010.

HAMM, J. J. A modified Azan staining technique for inclusion body viruses. Journal Invertebrate Pathology, v. 8, p. 125-126, 1966. https://doi.org/10.1016/0022-2011(66)90113-3

HONG, H. K.; WOO, S. D.; CHOI, J.Y.; LEE, H.K. Characterization of four isolates of Bombyx mori nucleopolyhedrovirus. Archives of Virology; v. 145, n. 11, p. 2351-2361, 2000.

https://doi.org/10.1007/s007050070025

JUNQUEIRA, L. C., JUNQUEIRA, L. M. M. S. Técnicas Básicas de Citologia e Histologia. São Paulo, Santos, p. 123, 1983.

KARNOVSKY, M. J. A formaldehyde-glutaraldehyde fixative of high osmolarity for use in electron microscopy. The Journal of Cell Biology, Boston, v. 27, 1965. 
KATAOKA, N.; MIYAKE, S.; AZUMA, M. Aquaporin and aquaglyceroporin en silkworms, differently expressed in the hindgut and midgut of Bombyx mori. Insect Molecular Biology, v. 18, n. 3, p. 303-314, 2009. https://doi.org/10.1111/j.1365-2583.2009.00871.x

KATSUMA, S.; NOGUCHI, Y.; SHIMADA, T.; NAGATA, M.; KOBAYASHI, M.; MAEDA, S. Molecular characterization of baculovirus Bombyx mori nucleopolyhedrovirus polyhedron mutants. Archives of Virology, v. 144 , p. $1275-1285,1999$. https://doi.org/10.1007/s007050050586

LEOPOLD, G.; KOSS, M. D. Cytologic and Histologic Manifestations of Human Papillomavirus Infection of the Female Genital Tract and Their Clinical Significance. Cancer, v. 60, p. 1942-1950, 1987.

https://doi.org/10.1002/1097-0142(19901015)60:8+<1942::AID-CNCR2820601504>3.0.CO;2-V

LEVY, S. M.; FALLEIROS, A. M. F.; MOSCARDI, F.; GREGÓRIO, E. A.; TOLEDO, L. A. Morphological study of the hindgut in larvae of Anticarsia gemmatalis Hubner ( Lepidoptera: Noctuidae). Neotropical Entomology, v. 33, n. 4, July-August, 2004. https://doi.org/10.1590/S1519-566X2004000400005

LEVY, S. M.; FALLEIROS, A. M. F.; MOSCARDI, F; GREGÓRIO, E. A.; TOLEDO, L. A. Ultramorphology of digestive tract of Anticarsia gemmatalis (Hübner, 1818) (Lepidoptera: Noctuidae) at final larval development. Semina: Ciências Agrarias, v. 29, p. 313-322, 2008. https://doi.org/10.5433/16790359.2008v29n2p313

LIANG, X.; LU, Z. L.; WEI, B. X.; FENG, J. L.; QU, D.; LUO, T. R. Phylogenetic analysis of Bombyx mori nucleopolyhedrovirus polyhedrin and p10 genes in wild isolates from Guangxi Zhuang Autonomous Region, China. Virus Genes, v. 46, p.140-151, 2013. https://doi.org/10.1007/s11262-012-0820-z

MARANHÃO, Z. C. Morfologia geral interna. In: Morfologia geral dos insetos. Nobel, São Paulo, SP, p. 204217, 1978.

MARTOJA, R.; BALLAN-DUFRANÇAIS, C. Digestive and excretory organs ultrastructure. In: KING, R. C.; AKAI, H. Insect ultrastructure, New York: Plenum Press, v. 2, p. 119-268, 1984.

https://doi.org/10.1007/978-1-4613-2715-8_6

MEANS, J. C.; PASSARELLI, A. L. Viralfibroblast growth factor, matrix metalloproteases, and caspases are associated with enhancing systemic infection by baculoviruses. PNAS, v. 107, p. 9825-9830, 2010. https://doi.org/10.1073/pnas.0913582107

MOSCARDI, F. Assessment of the application of baculoviruses for control of Lepidoptera. Annual Review of Entomology, v. 44, p. 257-289, 1999. https://doi.org/10.1146/annurev.ento.44.1.257

PASSARELLI, A. L. Barriers to success: how baculoviruses establish efficient systemic infections. Virology, v. 411, n. 2, p. 383-392, março, 2011. https://doi.org/10.1016/j.virol.2011.01.009

PEREIRA, E. P.; CONTE, H.; RIBEIRO, L. F. C.; ZANATTA, D. B.; BRAVO, J. P.; FERNANDEZ, M. A.; BRANCALHÃO, R. M. C.Cytopathological processby multiple Nucleopolyhedrovirus in the testis of Bombyx mori L., 1758 (Lepidoptera: bombycidae). Journal of Invertebrate Pathology, v. 99, n. 1, p. 1-7, maio, 2008. https://doi.org/10.1016/j.jip.2008.04.011

POTRICH, M.; ALVES, L. F. A.; BRANCALHÃO, R. C.; DALCIN, G. Entomopatógenos associados a lagartas de Bombyx mori L. (Lepidoptera: Bombycidae) no Estado do Paraná. Arquivos do Instituto Biológico, São Paulo, v. 74, n. 4, p. 363-367, out-dez, 2007.

QIN, L.; XIA, H.; SHI, H.; ZHOU, Y.; CHEN, L.; YAO, Q.; LIU, X.; FENG, F.; YUAN, Y.; CHEN, K. Comparative proteomic analysis reveals that caspase-1 and serine protease may be involved in silkworm resistance to Bombyx mori nuclear polyhedrosis virus. Journal of Proteomics, p. 3630-3638, 2012. https://doi.org/10.1016/j.jprot.2012.04.015 
RAHMAN, M. M.; GOPINATHAM, K. P.; Systemic and in vitro infection process of Bombyx mori nucleopolyhedrovirus.Virus Research, v. 101, n. 2, p. 109-118, maio, 2004.

https://doi.org/10.1016/j.virusres.2003.12.027

RIBEIRO, L. F. C.; BRANCALHÃO, R. M. C.; TORQUATO, E. F. B.; FERNANDEZ, M. A. Susceptibility of the Bombyx mori cardia cells to Nucleopolyhedrovirus, multiple subgroup, BmMNPV. Journal of Invertebrate Pathology, v. 100, n. 3, p. 195- 198, mar, 2009. https://doi.org/10.1016/j.jip.2009.01.001

RIGONI, G. M.; TOMATAKE, M. E. M.; CONTE, H. Morphology of Malpighian Tubules of Diatraea saccharalis (F.) (Lepidoptera: Crambidae) at Final Larval Devolopment. Cytologia, v. 69, n. 1, p. 1-6, 2004. https://doi.org/10.1508/cytologia.69.1

RODRÍGUEZ, J. L.; ROSA, J. C. CL.; PINEDO, E.; PINTO, D.; ZEDDAM, JL. Caracterización y utilización de un Nucleopoliedrovirus patógeno a Spodoptera eridania y S. ochrea. Manejo Integrado de Plagas, Costa Rica, n. 63, p. 39-45, 2002.

ROHRMANN, G. F. Baculovirus Molecular Biology. $3^{\circ}$ ed. Bethesda (MD): National Center for Biotechnology Information (US); NCBI; 2013.

SNODGRASS, R. E.; EICKWORT, G. C. Principles of Insect Morphology. Cornell University Press, New York. Cap. XIV, 1993.

SOARES, J. S.; RIBEIRO, B. M. Pathology of Anticarsia gemmatalis larvae infected by two recombinant Anticarsia gemmatalis multicapsid nucleopolyhedroviruses. Research in Microbiology, v. 156, p. 263-269, 2005. https://doi.org/10.1016/j.resmic.2004.09.015

SPRING, J. H.; PARKER, S. W.; HAZELTON, S. R. Excretion In The House Cricket (Acheta Domesticus): Ultrastructure Of The Ampulla And Ureter. Tissue \& Cell, v. 20, n. 3, p. 431-442, fev, 1988. https://doi.org/10.1016/0040-8166(88)90075-4

TEIGLER, D. J.; ARNOTT, H. J. Crystal Development In The Malpighian Tubules Of Bombyx Mori (L.). Tissue \& Cell, v. 4, n. 1, p. 173-185, 1972. https://doi.org/10.1016/S0040-8166(72)80014-4

TORQUATO, E. F. B.; MIRANDA-NETO, M. H. M.; BRANCALHÃO, R. M. C. Systematics, morphology and physiology nucleopolihedrovirus infected central nervous system cells of Bombyx mori (L.) (Lepidoptera: Bombycidae). Neotropical Entomology, Londrina, v. 35, n. 1, p. 70-74, jan-fev, 2006.

https://doi.org/10.1590/S1519-566X2006000100010

VAN OERS, M. M.; VLAK, J. M. The baculovirus 10-kDa protein. Journal Invertebrate Pathology, v. 70, p. 1-17, 1997. https://doi.org/10.1006/jipa.1997.4675

VESSARO-SILVA, S. A.; BRANCALHÃO, R. M. C.; BAGGIO, M. P. D.; RIBEIRO, L. F. C. Differential behavior of the rectum of Bombyx mori in relation to experimental inoculation with Alphabaculovirus.

Genetics and Molecular Research, v. 13, n. 3, p. 6885-6891, 2014. https://doi.org/10.4238/2014.August.29.10

YAO, Q.; LI, M. W.; WANG, Y.; WANG, W. B. Screening of molecular markers for NPV resistance in Bombyx mori L. (Lep., Bombycidae). Journal of Applied Entomology, v. 127, p. 134-136, 2003. https://doi.org/10.1046/j.1439-0418.2003.00741.x

WILLIAMS, G. V.; ROHEL, D. Z.; KUZIO, J.; FAULKNER, P. A Cytopathological Investigation of Autographa californica Nuclear Polyhedrosis Virus pl0 Gene Function Using Insertion/Deletion Mutants. Journal of General Virology, v. 70, p. 187-202, 1989. https://doi.org/10.1099/0022-1317-70-1-187 